\title{
Trichodesmium erythraeum (Ehrenberg) bloom along the southwest coast of India (Arabian Sea) and its impact on trace metal concentrations in seawater
}

\author{
Anoop A. Krishnan ${ }^{\text {a }}$, P.K. Krishnakumar ${ }^{\text {a,* }}$, M. Rajagopalan ${ }^{\mathrm{b}}$ \\ ${ }^{a}$ Research Centre of Central Marine Fisheries Research Institute, P.B. No. 244, Bolar, Mangalore 575 001, Karnataka, India \\ ${ }^{\mathrm{b}}$ Central Marine Fisheries Research Institute, P.B. No. 1603, Cochin 682014, Kerala, India
}

Received 27 June 2006; accepted 18 September 2006

Available online 24 October 2006

\begin{abstract}
The incidence of a large scale Trichodesmium erythraeum bloom along the southwest coast of India (Arabian Sea) observed in May 2005 is reported. Around 4802 filaments of T. erythraeum $\mathrm{ml}^{-1}$ seawater was observed and a colony consisted of $3.6 \times 10^{5}$ cells. The bloom was predominant off Suratkal $\left(12^{\circ} 59^{\prime} \mathrm{N}\right.$ and $\left.74^{\circ} 31^{\prime} \mathrm{E}\right)$ with a depth of about $47 \mathrm{~m}$, covering an area of $7 \mathrm{~km}$ in length and $2 \mathrm{~km}$ width. The concentrations of Zinc, Cadmium, Lead, Copper, Nickel and Cobalt were determined in samples collected from the bloom and non-bloom sites using stripping voltammetry. The observed hydrographical and meteorological parameters were found to be favorable for the bloom. The concentrations of Zinc, Cadmium and Nickel were found to be higher at bloom stations, while the concentrations of Lead, Copper and Cobalt were found to be very low at bloom stations. Elevated concentrations of Cadmium and Cobalt were observed at Valappad mainly due to the decomposition of detrital material produced in the bloom. Statistically significant differences $(P>0.01)$ in metal concentrations between the bloom and nonbloom stations were not observed except for Copper. Metals such as Lead, Copper and Cobalt were removed from the seawater at all places where bloom was observed. Cadmium was found to be slowly released during the decaying process of the bloom.
\end{abstract}

(C) 2006 Elsevier Ltd. All rights reserved.

Keywords: stripping voltammetry; Trichodesmium; cyanobacteria; trace metal; coastal water; Arabian Sea

\section{Introduction}

Cyanobacterial and algal blooms are often extremely 'patchy', both temporally and spatially. The patchy spatial distribution of plankton blooms is usually connected to the physical variability of the water body (Kononen and Leppänen, 1997). Patterns of patchiness in the sea are variable and continually shaped by the water movement, which either transports cyanobacterial and algal cells from one place to another or creates conditions for growth enhancement. The frequent appearance of phytoplankton blooms in marine environment has been reported from several parts of the world. The blooming of phytoplankton particularly Trichodesmium spp.

\footnotetext{
* Corresponding author.

E-mail address: krishnakumarpk@icqmail.com (P.K. Krishnakumar).
}

(cyanobacteria) generally occurs during February to May (pre-monsoon) in the coastal waters adjoining India (Qasim, 1970; Devassy et al., 1979b; Perumal et al., 1999; Jyothibabu et al., 2003; Sarangi et al., 2004). Stable hydrographic conditions and nutrient enrichment of surface waters through upwelling have been known to favour the occurrence of bloom. The non-heterocystous cyanobacterium Trichodesmium spp. is ubiquitous in tropical, subtropical, and temperate seas, forming some of the largest phytoplankton aggregations ever observed $\left(3.5 \times 10^{5} \mathrm{~km}^{2}\right.$ in the Arabian Sea, Capone et al., 1997). Cyanobacterium is considered as important primary producers and through nitrogen fixation can provide a source of nitrogen to their environment (Capone et al., 1997). There are five known marine species in the genus Trichodesmium spp.: Trichodesmium erythraeum, Trichodesmium hildebrantii, Trichodesmium contortum (Janson et al., 1995), Trichodesmium tenue and Trichodesmium thiebautii (Carpenter et al., 
1993). Of these, T. thiebautii and T. erythraeum are the most common species in tropical waters, the latter being the most prevalent in Indian coastal waters particularly Arabian Sea (Nair et al., 1992; Sarangi et al., 2004).

Phytoplankton affect the trace metal chemistry in natural waters by surface reactions, by taking up the metal directly, and by production of extra cellular organic matter with metal complexing properties (Moffett et al., 1990; Teresa et al., 2002). Coastal areas would have different trace metal concentrations from those in the open ocean because they would be influenced by local sources in surface and bottom waters. Productivity in coastal areas is generally several times higher than in the open ocean due to the influence of coastal upwelling or river run-off. One would expect these trace metals, which have high affinities for the biological activity, would show a characteristic behavior in coastal environments, especially when drastic biological production takes place (i.e. spring phytoplankton bloom). Only a few reports have been published on the behavior of trace metals during phytoplankton bloom (Noriki et al., 1985; Kudo and Matsunaga, 1998). Some work on metal concentrations during phytoplankton bloom has been done in a controlled mesocosm (Wangersky et al., 1989; Slauenwhite and Wangersky, 1991).

Detailed investigations on Trichodesmium spp. blooms have been carried from the coastal waters of Indian (James, 1972; Choudhury and Panigrahy, 1989; Satpathy and Nair, 1996). There are numerous reports on Arabian Sea and Indian Ocean blooms that suggest that blooms remain largely ungrazed and decompose, resulting in elevated ammonium levels and a succession of diatoms, dinoflagellates, and their grazers (Qasim, 1970; Steven and Glombitza, 1972; Devassy et al., 1979a,b; Borstad, 1982; Devassy, 1987; Nair et al., 1992). Trichodesmium spp. take up a number of trace metals from seawater, which is subsequently released as the cells decay (Jones et al., 1982). Reports on variations in trace metal concentrations during Trichodesmium spp. bloom are scarce. In this paper we present the changes in the concentrations of dissolved Zinc, Cadmium, Lead, Copper, Nickel and Cobalt during a Trichodesmium erythraeum bloom in Arabian Sea adjoining the southwest coast of India.

\section{Material and methods}

\subsection{Site description and sampling}

During the cruise of FORV Sagar Sampada from 6th to 20th May 2005 (Arabian Sea), extensive greenish-yellow patches of algal bloom were observed at seven places along the west coast of India from Mangalore to Quilon $\left(09^{\circ}\right.$ to $13^{\circ} \mathrm{S}$ latitude) (Fig. 1). A total of five sea water samples were collected for heavy metal analysis as per the details given in Table 1. Three samples were collected from bloom stations (Cochin, Suratkal, 'healthy stage' and Valappad, 'decayed stage') and two from non-bloom stations (Mangalore) for comparison. Water samples were collected from the surface using Niskin samplers from the selected locations. Samples were collected in acid washed polypropylene flasks separately

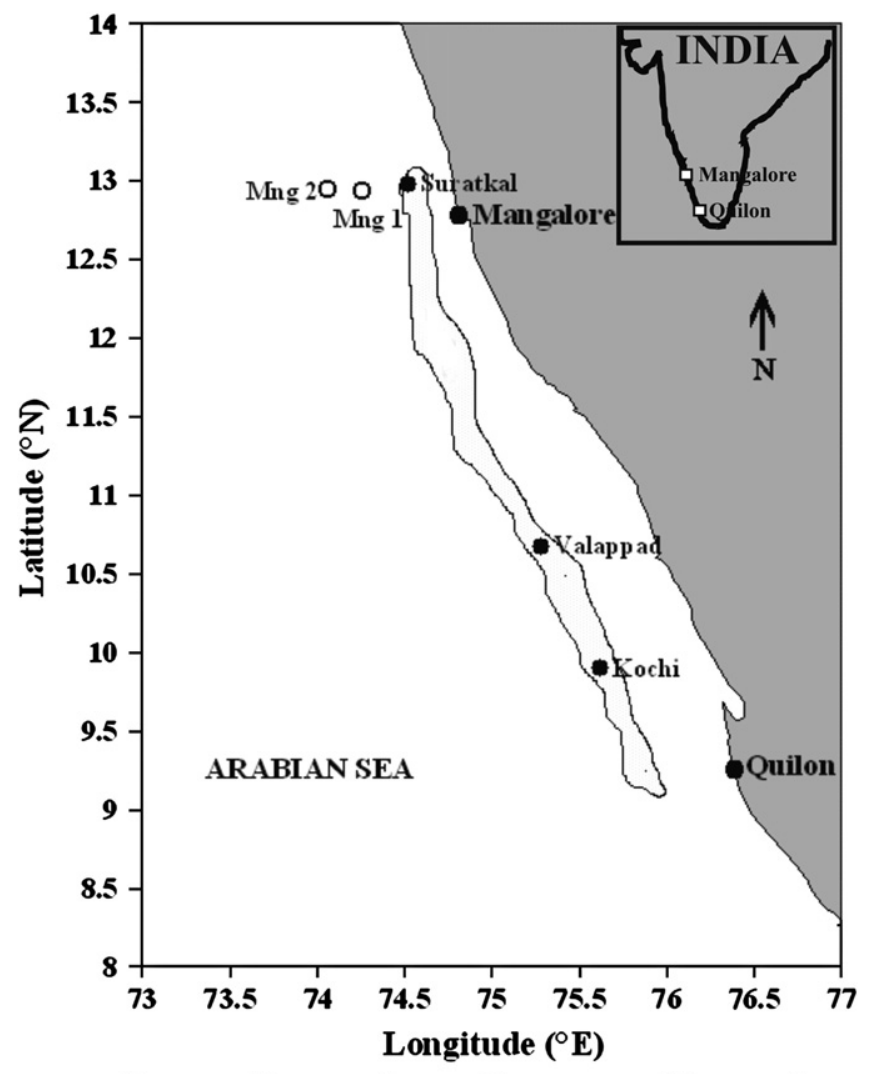

- Represent bloom stations O Represent non bloom stations

Shaded area represents the patch of bloom observed

Fig. 1. Map showing the sampling stations. Represents bloom stations. $\bigcirc$ Represents non-bloom stations. Dotted areas represent the patch of bloom observed.

for metal analysis and for identification of the bloom. Bloom samples (phytoplankton) collected were preserved in Lugols solution for identification and further counting using Sedgwick-Raftor counting cell. The phytoplankton samples were identified with the help of light Microscope (Olympus BX 50). Seawater samples were filtered through a $0.45 \mu \mathrm{m}$ cellulose acetate filter and organic matter was digested by adding $\mathrm{HNO}_{3}$ (Merck-Suprapur) to a final $\mathrm{pH}$ of $<2$ and kept in deep freezer for analysis of major elements $(\mathrm{Zn}, \mathrm{Cd}, \mathrm{Pb}, \mathrm{Cu}$, $\mathrm{Ni}$ and $\mathrm{Co}$ ). Clean procedures were used in order to avoid contamination of water samples. The various meteorological parameters (wind speed, wind direction, air temperature, humidity, pressure and solar radiation) were monitored by an automatic weather station on-board the ship. Salinity and dissolved oxygen were determined from Sea-Bird Electronics

Table 1

Details of stations from where samples were collected for the study

\begin{tabular}{lllll}
\hline Stations & Latitude $\left({ }^{\circ} \mathrm{N}\right)$ & Longitude $\left({ }^{\circ} \mathrm{E}\right)$ & Date of sampling & Bloom \\
\hline Mng 1 & $13^{\circ} 00$ & $74^{\circ} 54$ & $10 / 5 / 2005$ & absent \\
Mng 2 & $12^{\circ} 59$ & $73^{\circ} 53$ & $10 / 5 / 2005$ & absent \\
Surtakal & $12^{\circ} 59$ & $74^{\circ} 31$ & $10 / 5 / 2005$ & present \\
Valappad & $10^{\circ} 41$ & $75^{\circ} 17$ & $13 / 5 / 2005$ & present \\
Kochi & $09^{\circ} 54$ & $75^{\circ} 37$ & $14 / 5 / 2005$ & present \\
\hline
\end{tabular}


CTD (USA, model: SBE-911 plus) data and the sea surface temperature (SST) was measured using a bucket-thermometer.

\subsection{Determination of trace metals by Stripping Voltammetry}

Metals were analysed using Stripping Voltammetry in a 757 VA Computrace attached to 765 Dosimat (Metrohm, Switzerland). Total dissolved $\mathrm{Zn}, \mathrm{Cd}, \mathrm{Pb}$ and $\mathrm{Cu}$ were estimated by adding $10 \mathrm{ml}$ sample and $1 \mathrm{ml}$ acetate buffer in a Teflon cell, using Differential Pulse Anodic Stripping Voltammetry (DPASV). The concentrations of these metals were simultaneously measured by addition of mixed metal standards (Florence, 1972) using Dosimat. The detection limit for $\mathrm{Zn}, \mathrm{Cd}, \mathrm{Pb}$ and $\mathrm{Cu}$ were $500,50,50$ and $50 \mathrm{ppt}$ respectively. Total dissolved $\mathrm{Ni}$ and $\mathrm{Co}$ were estimated using Cathodic Stripping Voltammetry (CSV) by adding $10 \mathrm{ml}$ sample, 0.05 dimethyl glycoxime (DMG) and $0.5 \mathrm{ml} \mathrm{NH}_{3}$ buffer (Meyer and Neeb, 1983) into the Teflon cell and analyzed using respective standards. The detection limit of $\mathrm{Ni}$ and Co was $50 \mathrm{ppt}$. A hanging drop electrode was used as working electrode, and potential were measured versus Potassium chloride $\left(3 \mathrm{~mol} \mathrm{l}^{-1}\right)$ reference electrode and an auxiliary platinum electrode for estimation of all the trace metals. The results presented are blank corrected. The accuracy of the analytical procedure was checked using certified reference material BCR - 403 (Community Bureau of Reference). The recovery was $99 \%$ for all metal studied, which was estimated by measuring standard spiked samples. All handling was processed in a clean room. To infer the distribution of bloom and its impact on trace metals, hydrographical and meteorological parameters in the study area the data was subjected to statistical analysis to test the Analysis of Variance (ANOVA) using SPSS 7.5 statistical package.

\section{Results}

\subsection{Distribution of Trichodesmium erythraeum}

Colonies of the cyanobacterium $(2-3 \mathrm{~mm}$ size bundles of trichomes) could be seen with the naked eye in the surface water at several stations along the cruise track. During the entire cruise, surface water was blooming with this cyanobacterium, possibly the dominant primary producer during this period. It appeared that Trichodesmium spp. was concentrated in the upper 3 meters of the water column (Cochin and Suratkal), and underwater aggregates became abundant towards the latter part of the bloom. Towards the latter part of the cruise (Valappad), the water became visibly thick with the bloom. The surface water attained a brownish color, and the sea conditions were flat calm. It is noteworthy that Trichodesmium spp. blooms occur in the warm (summer) nutrient-poor tropical/ subtropical ocean only under very calm conditions.

Analysis of the surface plankton collections revealed the presence of Trichodesmium erythraeum in the sample. Around 4802 filaments of T. erythraeum $\mathrm{ml}^{-1}$ seawater was observed. A colony of T. erythraeum collected from the bloom stations consisted of $3.6 \times 10^{5}$ cells. This cyanobacterium is strongly pigmented comprising approximately $99 \%$ of total cell count and there were many phytoflagellates present in the fixed sample. The T. erythraeum found off Valappad showed green pigments and some filaments were even white in colour which suggests that they were in the 'decayed phase' of bloom. The bloom off Cochin and Suratkal showed a brownish to red colour which suggest that the bloom was in the "healthy phase'. The bloom was predominantly off Suratkal $\left(12^{\circ}\right.$ $59^{\prime} \mathrm{N}$ and $74^{\circ} 31^{\prime} \mathrm{E}$ ) which has a depth of about $47 \mathrm{~m}$, covering an area of $7 \mathrm{~km}$ in length and $2 \mathrm{~km}$ width and was seen about $30 \mathrm{~km}$ from the shore. The general hydrographic and meteorological conditions as recorded from CTD and AWS a re given in Table 2 .

\subsection{Hydrography and trace metal concentrations}

Observations on the hydrographic conditions of the surface water at all places where bloom was sighted revealed a seawater temperature of $30.3-30.9{ }^{\circ} \mathrm{C}$ and salinity ranging from 34.96 to 35.4. The dissolved oxygen was found to be $2.24 \mathrm{mg} \mathrm{l}^{-1}$ at Valappad. The air temperature was found to be around $30.0^{\circ} \mathrm{C}$, the wind speed ranged from 3.7$4.5 \mathrm{~m} \mathrm{sec}^{-1}$. Humidity and the pressure were found to be high ranging from $67-77.2 \%$ and $1006.8-1009$ mbar respectively. Solar radiation which influences the occurrence of bloom was ranging from $76.2-86.3 \mathrm{nWsq} \mathrm{cm}^{-1}$ (Table 2).

The $\mathrm{Zn}$ concentrations at the bloom stations ranged from 26.92 to $91.99 \mu \mathrm{g} \mathrm{l}^{-1}$, with a mean of $55.39 \mu \mathrm{g} \mathrm{l}^{-1}$ while at the non-bloom stations it ranged from 10.79 to $64.39 \mu \mathrm{g} \mathrm{l^{-1 }}$ with a mean of $28.73 \mu \mathrm{g}^{-1}$ (Fig. 2). Highest Zn concentrations of $91.99 \mu \mathrm{g} \mathrm{l}^{-1}$ were observed in the bloom station off Cochin while lowest concentrations of $10.79 \mu \mathrm{g} \mathrm{l^{-1 }}$ were observed in the non-bloom station off Mangalore. The Cd concentrations at the bloom stations ranged from 0.31 to $1.16 \mu \mathrm{g} \mathrm{l}^{-1}$ with a mean of $0.65 \mu \mathrm{g} \mathrm{l}^{-1}$ while at non-bloom stations it ranged from 0.32 to $0.58 \mu \mathrm{g} 1^{-1}$ with a mean of $0.48 \mu \mathrm{g}^{-1}$ (Fig. 2). Highest $\mathrm{Cd}$ concentrations of $1.16 \mu \mathrm{g}^{-1}$ were observed in the bloom station off Valappad and the lowest concentrations of $0.31 \mu \mathrm{g} \mathrm{l}^{-1}$ was also observed at bloom stations off Cochin (Fig. 2). The Pb concentrations at the bloom stations was found to be below detection limit

Table 2

General hydrographical and meteorological condition at bloom stations

\begin{tabular}{|c|c|c|c|}
\hline Parameters & Suratkal & Valappad & Cochin \\
\hline SST & $30.3{ }^{\circ} \mathrm{C}$ & $30.7^{\circ} \mathrm{C}$ & $30.68^{\circ} \mathrm{C}$ \\
\hline Salinity & 35.4 & 35.27 & 34.96 \\
\hline Wind speed & $4.5 \mathrm{~m} \mathrm{sec}^{-1}$ & $4.5 \mathrm{~m} \mathrm{sec}^{-1}$ & $3.7 \mathrm{~m} \mathrm{sec}^{-1}$ \\
\hline $\begin{array}{l}\text { Wind } \\
\text { direction }\end{array}$ & $9.6^{\circ}$ & $291.3^{\circ}$ & $316.3^{\circ}$ \\
\hline $\begin{array}{l}\text { Air } \\
\quad \text { temperature }\end{array}$ & $30.1^{\circ} \mathrm{C}$ & $30.0^{\circ} \mathrm{C}$ & $30.0^{\circ} \mathrm{C}$ \\
\hline Humidity & $67.0 \%$ & $77.2 \%$ & $72.5 \%$ \\
\hline Pressure & $1009.0 \mathrm{~m}$ bar & $1006.8 \mathrm{~m}$ bar & $1007.9 \mathrm{~m}$ bar \\
\hline $\begin{array}{l}\text { Solar } \\
\text { radiation }\end{array}$ & $76.2 \mathrm{nWsq} \mathrm{cm}^{-1}$ & $86.376 .2 \mathrm{nWsq} \mathrm{cm}^{-1}$ & $79.376 .2 \mathrm{nWsq} \mathrm{cm}^{-1}$ \\
\hline
\end{tabular}



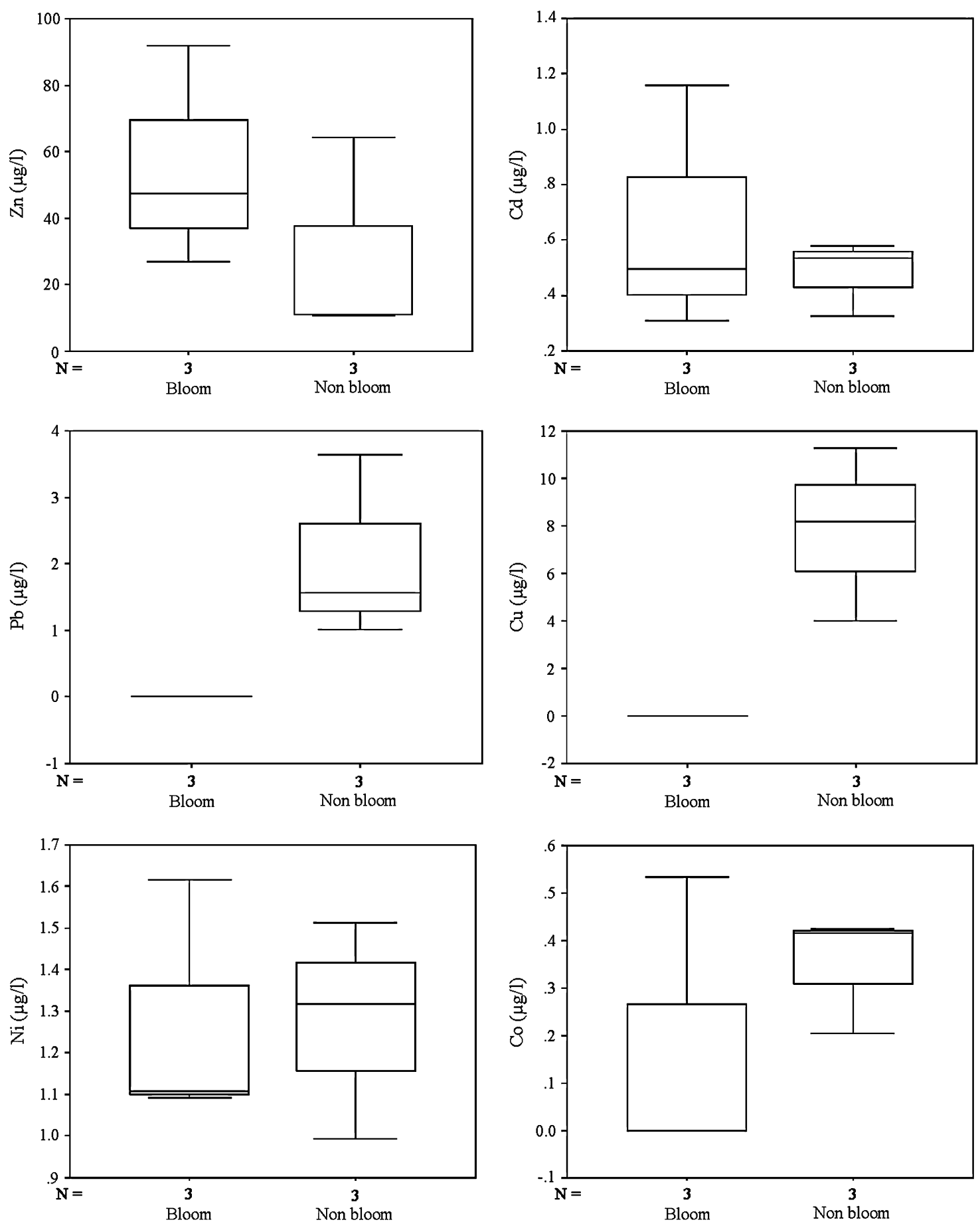

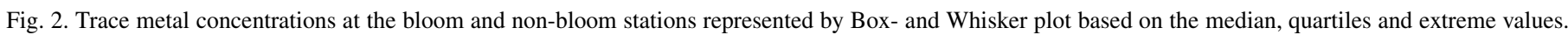

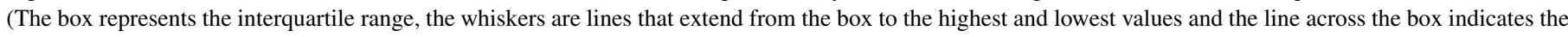
median).

(BDL), while at non-bloom stations it ranged from 1.01 to $3.64 \mu \mathrm{g}^{-1}$ with a mean of $2.07 \mu \mathrm{g} \mathrm{l}^{-1}$ (Fig. 2). The $\mathrm{Cu}$ concentrations at the bloom stations was found to be below detection limit (BDL), while at non-bloom stations it ranged from 4.02 to $11.26 \mu \mathrm{g} \mathrm{l}^{-1}$ with a mean of $7.82 \mu \mathrm{g} \mathrm{l}^{-1}$ (Fig. 2). The $\mathrm{Ni}$ concentrations at the bloom stations ranged from 1.09 to $1.62 \mu \mathrm{g}^{-1}$ at the surface with a mean of $1.27 \mu \mathrm{g}^{-1}$ while at non-bloom stations it ranged from 0.99 to $1.51 \mu \mathrm{g} 1^{-1}$ with a mean of $1.28 \mu \mathrm{g} \mathrm{l} l^{-1}$. Highest Ni concentrations of $1.62 \mu \mathrm{g}^{-1}$ was observed in the bloom station off Cochin while the lowest value of $0.99 \mu \mathrm{g} \mathrm{l}^{-1}$ was observed in the non-bloom station off Mangalore (Fig. 2). The Co concentrations at the bloom stations range from BDL to $0.53 \mu \mathrm{g} l^{-1}$ at the surface, while at non-bloom stations it ranged from 0.20 
to $0.43 \mu \mathrm{g} 1^{-1}$ with a mean of $0.35 \mu \mathrm{g} 1^{-1}$. Highest Co concentrations of $0.53 \mu \mathrm{g}^{-1}$ was observed in the bloom station off Valappad while the lowest value of $0.20 \mu \mathrm{g} \mathrm{l}^{-1}$ was observed in the non-bloom station off Mangalore (Fig. 2). No statistically significant differences $(P>0.01)$ were observed in metal concentrations between the bloom and non-bloom stations except for $\mathrm{Cu}$ where it showed a significant difference $(P<0.01)$.

\section{Discussion}

Along the west coast of India, the phytoplankton bloom is usually observed during the southwest monsoon season starting from May to September (Subrahmanyam, 1973). Blooms are most conspicuous in calm conditions, with trichomes forming dense mats or rafts on the surface of the ocean. Calm conditions at sea and water temperatures $<21{ }^{\circ} \mathrm{C}$ assist the formation of bloom (Marumo and Asaoka, 1974; Carpenter and Price, 1976; Carpenter and Romans, 1991; Suvapepun, 1992). Most marine cyanobacteria exist in temperatures ranging from $-5{ }^{\circ} \mathrm{C}$ to $35^{\circ} \mathrm{C}$, exhibiting temperature optima somewhere in the range of $25-35^{\circ} \mathrm{C}$ (Fogg et al., 1973). Generally, cyanobacteria require higher temperature optima for growth than other phytoplankton and the temperature has been considered the most important factor contributing to cyanobacterial dominance (Suvapepun, 1992; Sellner, 1997). Usually low dissolved oxygen values are observed in seawater near the bloom when it is in the decayed stage (Choudhury and Panigrahy, 1989; Suvapepant, 1995).

A thick bloom of Trichodesmium erythraeum was observed throughout the cruise track in the present study. Bloom formation and the accumulation of a scum on the water surface, is a result of a change in weather conditions (e.g. Walsby, 1994). Buoyancy regulation by cyanobacteria plays a key role in this phenomenon. Once a large dominant cyanobacterial population has developed in a water body, the continuous turbulence, mixing of the water body and the decrease in light penetration cause cyanobacteria to increase their buoyancy. As soon as the wind abates, cyanobacteria float rapidly towards the surface due to their 'over-buoyancy' (Sellner, 1997). The surface accumulations are quickly dispersed over the water column by wind-induced mixing at wind speeds over 6$8 \mathrm{~m} \mathrm{~s}^{-1}$ (Kahru et al., 1993). If the wind energy is not strong enough to redisperse the cells into the water column, cyanobacteria accumulate on the water surface as observed in the present study (Table 2). As Trichodesmium spp. tolerates higher irradiances (Table 2), their filaments will concentrate and can survive near the surface during calm and sunny periods.

Blooms are associated with significant enrichments in a number of dissolved and particulate trace metals as in the case of $\mathrm{Zn}$ and Ni found off Cochin and Suratkal during this study. Concentrations of $\mathrm{Zn}$ varied little between 'healthy' and 'decayed' samples thus suggesting negligible biological uptake or release. Laboratory culture experiment has shown that Cyanobacteria did not require $\mathrm{Zn}$ for growth, however they do appear to have an absolute requirement for Co (Sunda and Huntsman, 1995). Cadmium concentrations were generally higher in seawater samples from Valappad (decayed phase) compared to Cochin and Suratkal (healthy phase). This suggests that physical conditions can influence $\mathrm{Cd}$ transformations. From this study it has been well-demonstrated that the chemical speciation of $\mathrm{Cu}$ and $\mathrm{Zn}$ significantly affects the bioavailability of these metals to phytoplankton compared to other work done (Sunda and Guillard, 1976; Anderson et al., 1978). Concentrations of $\mathrm{Zn}, \mathrm{Cd}$, and $\mathrm{Ni}$ were generally high at bloom stations when compared with non-bloom stations. Generally, the apparent removal of $\mathrm{Pb}$ and $\mathrm{Cu}$ from all the three bloom stations was observed (Fig. 2) and Co from Cochin and Suratkal where the bloom was in healthy phase, a case of accumulation of metals. Earlier workers have observed discoloration of water, production of offensive smell and mortality of fishes and other organisms in the coastal water due to Trichodesmium spp. bloom (Chacko, 1942; Chidambaram and Unny, 1944). There was however no report of fish mortality during this observation.

Current data on variations in trace metal concentrations from bloom and non-bloom sites underline the influence of trace metals in Trichodesmium erythraeum bloom. The cyanobacteria have relatively high temperature optima thus, if the temperature conditions are not favourable then even high nutrient concentrations in the upwelling areas cannot facilitate the cyanobacterial growth. In general, Trichodesmium spp. blooms are a natural part of marine ecology and are not harmful to the ecosystem. A continuous monitoring of physicochemical parameters of coastal water in the study area on a long term basis would help in understanding the cause of bloom and the influence of trace metal concentration on bloom formation.

\section{Conclusion}

Trichodesmium erythraeum bloom is common in tropical waters and along the Southwest coast of India. The Trichodesmium spp. is largely confined to the surface and occurs in varying intensity almost every year from February to May along west coast of India. Concentrations of $\mathrm{Zn}, \mathrm{Cd}$ and $\mathrm{Ni}$ showed higher values at places were the bloom was observed. Metals such as $\mathrm{Pb}, \mathrm{Cu}$ and $\mathrm{Co}$ were removed from the seawater at all places where bloom was observed. Cadmium was found to be slowly released during the decaying process of the bloom.

\section{Acknowledgments}

We are extremely grateful to our Director for his encouragement and for facilities provided and to Dr. C. Muthiah, Scientist-in-Charge, RC of CMFRI, Mangalore and all our other colleagues in CMFRI for their constant helps and encouragements. We are thankful to the Chief Scientist, Dr. G.E. Nampoothiri, National Institute of Oceanography for the support, he provided for carrying out the study. N. Harish, S. Veena and Anitha offered helpful suggestions during manuscript preparation. We sincerely thank Dr. Raveendranath, DOD for funding this work and the crews of FORV Sagar Sampada for their able assistance in carrying out this work. 


\section{References}

Anderson, M.A., Morel, F.M.M., Guillard, R.R.L., 1978. Growth limitation of a coastal diatom by low zinc ion activity. Nature 276, 70-71.

Borstad, G.A., 1982. The influence of the meandering Guiana current on surface conditions near Barbados-temporal variations of Trichodesmium (Cyanophyta) and other plankton. Journal of Marine Research 40, 435-452.

Capone, D.G., Zehr, J.P., Paerl, H.W., 1997. Trichodesmium, a globally significant marine cyanobacterium. Science 276, 1221-1229.

Carpenter, E.J., Price, C.I.V., 1976. Marine Oscillatoria (Trichodesmium): explanation for aerobic nitrogen fixation without heterocysts. Science 191, $1278-1280$.

Carpenter, E.J., Romans, K., 1991. Major role of the cyanobacterium Trichodesmium in nutrient cycling in the North Atlantic Ocean. Science 254, $1356-1358$.

Carpenter, E.J., O'Neil, J.M., Dawson, R., Capone, D.G., Siddiqui, P.J.A., Roenneberg, T., Bergman, B., 1993. The tropical diazotrophic phytoplankter Trichodesmium: biological characteristics of two common species. Marine Ecology Progress Series 95, 295-304.

Chacko, P.I., 1942. An unusual incidence of mortality of marine fauna. Current Science 11, 404.

Chidambaram, K., Unny, M.M., 1944. Note on the swarming of the planktonic alga Trichodesmium erythraeum in the Pamban area and its effect on the fauna. Current Science 13, 263.

Choudhury, S.B., Panigrahy, R.C., 1989. Occurrence of bloom of diatom Astenrionella glacialis in nearshore waters of Gopalpur, Bay of Bengal. Indian Journal of Marine Sciences 18, 204.

Devassy, V.P., 1987. Trichodesmium red tides in the Arabian Sea. In: Rao, T.S.S., et al. (Eds.), Contributions in Marine Sciences: A Special Volume to Felicitate Dr. S.Z. Qasim Sastyabdapurti on His Sixtieth Birthday. National Institute of Oceanography, Dona Paula, India, pp. 61-66.

Devassy, V.P., Bhattathiri, P.M.A., Qasim, S.Z., 1979a. Succession of organisms following Trichodesmium phenomenon. Indian Journal of Marine Sciences 8, 89-93.

Devassy, V.P., Bhattathiri, P.M.A., Qasim, S.Z., 1979b. Trichodesmium phenomenon. Indian Journal of Marine Sciences 7, 168-186.

Florence, T.M., 1972. Determination of trace metals in marine samples by anodic stripping voltammetry. Journal of Electro-analytical Chemistry 35, 237-245.

Fogg, G.E., Stewart, W.D.P., Fay, P., Walsby, A.E., 1973. The Blue-Green Algae. Academic Press, London.

James, P.S.B.R., 1972. On a bloom of Trichodesmium thiebautii Gomont in the Gulf of Mannar at Mandapam. Indian Journal of Fisheries 19, 205-207.

Janson, S., Siddiqui, P.J.A., Walsby, A.E., Romans, K.M., Carpenter, E.J., Bergman, B., 1995. Cytomorphological characterization of the planktonic diazotrophic cyanobacteria Trichodesmium spp. from the Indian Ocean, Caribbean and Sargasso Seas. Journal of Phycology 31, 463-477.

Jones, G.B., Burdon-Jones, C., Thomas, F.G., 1982. Influence of Trichodesmium red tides on trace metal cycling at a coastal station in the Great Barrier Reef lagoon. Oceanologica Acta 5, 319-326.

Jyothibabu, R., Madhu, N.V., Murukesh, N., Haridas, P.C., Nair, K.K.C., Venugopal, P., 2003. Intense blooms of Trichodesmium erythraeum (Cyanophyta) in the open waters along East Coast of India. Indian Journal Marine Sciences 32, 165-167.

Kahru, M., Leppänen, J.M., Rud, O., 1993. Cyanobacterial blooms cause heating of the sea surface. Marine Ecology Progress Series 101, 1-7.

Kononen, K., Leppänen, J.M., 1997. Patchiness, scales and controlling mechanisms of cyanobacterial blooms in the Baltic Sea: application of a multiscale research strategy. In: Kahru, M., Brown, Ch.W. (Eds.), Monitoring Algal Blooms: New Techniques for Detecting Large-Scale Environmental Change. Landes Bioscience, Austin, TX, USA, pp. 63-84.
Kudo, I., Matsunaga, K., 1998. Behaviour of $\mathrm{Cu}$, $\mathrm{Ni}$ and $\mathrm{Cd}$ during Nutrient depletion in a spring bloom in Funka Bay. Journal of Oceanography 54, 619-627.

Marumo, R., Asaoka, O., 1974. Distribution of pelagic blue-green algae in the North Pacific Ocean. Journal of the Oceanographical Society of Japan 30, $77-85$

Meyer, A., Neeb, R., 1983. Determination of Co and Ni by adsorption voltammetry in supporting electrolytes containing triethanolamine and dimethylglyoxime. Analytical Chemistry 315, 118-120.

Moffett, J.W., Brand, L.E., Zika, R.G., 1990. Distribution and potential sources and sinks of copper chelators in the Sargasso Sea. Deep-Sea Research I 37, $27-36$.

Nair, V.E., Devassy, V.P., Madhuprathap, M., 1992. Blooms of phytoplankton along the coast of India associated with nutrient enrichment and the response of zooplankton. In: Vollenweiden, R.A., et al. (Eds.), Marine Coastal Eutrophication. Science of Total Environment. Elsevier, pp. 819-828.

Noriki, S., Ishimori, N., Harada, K., Tsungai, S., 1985. Removal of trace metals from sea water during a phytoplankton bloom as studied with sediment traps in Funka Bay, Japan. Marine Chemistry 17, 75-89.

Perumal, P., Sampathkumar, P., Karuppasamy, P.K., 1999. Studies on the bloom forming species of phytoplankton in the Vellar estuary, southeast coast of India. Indian Journal of Marine Sciences 28, 400-403.

Qasim, S.Z., 1970. Some characteristics of a Trichodesmium bloom in the Laccadives. Deep-Sea Research 17, 55-660.

Sarangi, R.K., Prakash, C., Nayak, S.R., 2004. Detection and monitoring of Trichodesmium blooms in the coastal waters off Saurashtra coast, India using IRS-P4 OCM data. Current Science 86, 1636-1641.

Satpathy, K.K., Nair, K.V.K., 1996. Occurrence of phytoplankton bloom and its effect on coastal water quality. Indian Journal Marine Sciences 25, $145-147$.

Sellner, K.G., 1997. Physiology, ecology and toxic properties of marine cyanobacteria blooms. Limnology and Oceanography 42, 1089-1104.

Slauenwhite, D.E., Wangersky, P.J., 1991. Behaviour of copper and cadmium during a phytoplankton bloom: a mesocosm experiment. Marine Chemistry $32,37-50$.

Steven, D.M., Glombitza, R., 1972. Oscillatory variation of a phytoplankton population in a tropical ocean. Nature 237, 105-107.

Subrahmanyam, R., 1973. Hydrography and plankton as indicator of marine resources. In: Qasim, S.Z. (Ed.), Proceedings of the Symposium on Living resources of the seas around India. Central Marine Fisheries Research Institute (CMFRI) Special Publication, pp. 199-228.

Sunda, W.G., Guillard, R.R.L., 1976. The relationship between cupric ion activity and the toxicity of copper to phytoplankton. Journal of Marine Research 34, 511-529.

Sunda, W.G., Huntsman, S.A., 1995. Cobalt and zinc inter-replacement in marine phytoplankton: biological and geochemical implications. Limnology and Oceanography 40, 1404-1417.

Suvapepant, S., 1995. Red tides and red tides research in Thai waters. In: Suvapepant, S., Lertvidhayaprasit, T. (Eds.), Red Tides. Dept of Fisheries, Bangkok (in Thai), pp. 1-11.

Suvapepun, S., 1992. Trichodesmium blooms in the Gulf of Thailand. In: Carpenter, E.J., et al. (Eds.), Marine Pelagic Cyanobacteria: Trichodesmium and Other Diazotrophs. Kluwer, pp. 343-348.

Teresa, M.S.D., Fernada, M.C.L., Constant, M.G., 2002. Influence of the nature of the exudates released by different marine algae on the growth of trace metal uptake and exudation of Emiliania huxleyi in natural Seawater. Marine Chemistry 77, 187-210.

Walsby, A.E., 1994. Gas vesicles. Microbiological Reviews 58, 94-144.

Wangersky, P.J., Moran, S.B., Pett, R.J., Slauenwhite, D.E., Ahou, X., 1989. Biological control of trace metal residence times: an experimental approach. Marine Chemistry 28, 215-226. 